\title{
Why National Capacity Affects the Level of Technological Progress: Based on the Experience of Asian Countries
}

\author{
Haibin Yang \\ School of International Business \\ Yunnan University of Finance and Economics \\ Kunming, China \\ haibinyoung@foxmail.com
}

\begin{abstract}
Maintaining technological progress and growing national capacity in the process of opening up is an important condition for sustained economic growth in developing countries. The new economic normality that has emerged since the international financial crisis has fully highlighted the characteristics of the unbalanced pattern of the world economy, while having a clear impact on emerging economies represented by China and India. Using the interprovincial data of total factor productivity (TFP), this paper compares the technological progress between China and India under open conditions, and finds that technological progress is a long-term accumulation process of learning and imitating advanced technology, and the corresponding growth of national capacity is the key to success.
\end{abstract}

Keywords: technological progress, capacity growth, developing countries

\section{INTRODUCTION}

Since the 1990s, the center of gravity of the world economy has gradually completed a large-scale shift from west to east and from north to south. In this regard, some economists believe that the transformation of the global economy to a large extent from emerging market technology development level and national economic development maturity. As a "locomotive" country representing the economic growth of developing countries in the past 30 years, China and India have obviously accelerated the pace of integration with the world economy, marked by the accession to the WTO, and have become open economies with the largest amount of FDI and high dependence on foreign trade, foreign trade dependence on a high degree of open economy.

What must not be ignored, however, is that behind the unprecedented 6\%-10\% economic growth rate in India and China, there is a different development model between the two countries. With the industrialization of China and India and the deepening of urbanization, both economies are undergoing significant structural changes. In particular, in the aftermath of the 2008 world financial crisis, as a result of reduced demand from industrialized countries, the dividends of the first wave of export-led globalization have been overdrawn in the past by joining global value chains with low-end elements, The era of "structural acceleration" leading to simultaneous high growth between the two countries has come to an end, and economic growth will gradually shift to a "structural slowdown" in the future.

Therefore, in the post-crisis era, China and India must change their economic development as soon as possible. Judging from the experience of western developed countries in the past, modern economic growth is based on the continuous evolution and development of technology, enterprises and industrial structures, but with knowledge. Organizational and institutional national capacity development is undoubtedly a key variable in this process of economic development. In order to explore in-depth the role of capacity growth in changing the mode of economic development, this paper will start from the analysis of the national capacity composition of developing countries, and take the technological capacity changes caused by FDI in China and India as the object. Trying to answer the main question of why developing countries such as China and India, in order to complete their economic transformation under the conditions of economic opening, must change the original growth model of relying solely on the input of resources and capital to gain access to technology, Then realize the structural transformation to rely mainly on independent innovation strategy-based capacity development?

\section{SOURCES AND CHARACTERISTICS OF TECHNOLOGICAL PROGRESS IN DEVELOPING COUNTRIES}

Endogenous economic growth theory always regards technological progress as "the engine of a country's sustainable economic development". However, since this proposition is based on the experience of developed economies, the new proposition of how developing countries can achieve technological progress in an open economy, It is necessary to consider the relationship between technological progress and economic growth from three aspects: firstly, it is necessary to consider the mechanism and influencing factors of endogenous technological progress in developing countries under open conditions. Generally speaking, most developing countries obtain technological progress mainly through the purchase of patents, foreign investment, import and export products and so on, resulting in direct technology transfer, spillover effect and dry middle school effect. Secondly, technological progress and economic convergence in developing countries need to be considered. In view of this, 
the neo-classical theory of international trade holds that the developing countries cannot bring the growth effect to the open economy except for the horizontal effect, nor can they guarantee the increase of their economic growth rate and the convergence to the developed economies. However, if the comparative advantage of developing countries in an open economy is taken into account, the quasi-public goods nature of technology and the diffusion of technology will enable developing countries to gain late advantage through low-cost learning and imitation; thirdly, the impact of economic policies in developing countries on technological progress needs to be considered. For the economic policy of developing countries, more attention needs to be paid to the transformation of economic system and the change of factor structure. Therefore, although there is no strong empirical research to support the impact of policy intervention on technological progress, we can still examine the openness and freedom of policy from the perspective of technological progress effect produced by international trade.

According to the traditional theory of dynamic comparative advantage, although the development of an industry does not conform to the country's comparative advantage at present, as long as the government protects and guides the industry through industrial policies, it will conform to the future comparative advantage when the industry grows to a certain scale. In order to catch up with developed countries, China and India, two countries in the stage of economic catch-up, artificially supported many industries that did not conform to their own comparative advantages in the past. However, as China and India lack the ability to imitate and absorb advanced technologies, they cannot support these industries without their own capabilities. It is difficult for them to gain technological progress from knowledge transfer, let alone benefit from technology spillover from foreign trade, and finally it is difficult for them to transform into dynamic comparative advantages. It can be seen that the effective technological capacity of developing countries is a very important precondition for their participation in global industrial division and international trade. It also inspires us to further consider the relationship between capacity, technology and economic growth in the development process of economies in transition, especially how developing countries realize the transition from technology learning to independent innovation, and the endogenous role of capacity growth in the process of technological progress.

It is undeniable that although the theory of endogenous growth attaches great importance to the long-term impact of technological progress on economic growth, it seldom analyzes the spillover and diffusion process of technology from the micro level. Due to the impact of technology diffusion, the division of labor in technology cannot serve as the basis for long-term comparative advantage. The existence of economic phenomena in reality also indicates that there is still a huge technological gap between developed and backward countries. Therefore, we should not simply attribute all the problems that cannot be explained to technology, but clarify the connotation and essence of technological progress. First, the sources of technological progress need to be identified. In this regard, since Schumpeter put forward the concept of "innovation", the academia generally believed that technological progress brought by innovation activities based on optimized resource allocation promoted economic growth. Second, the heterogeneity of technological progress needs to be clarified. Obviously, Schumpeter did not distinguish whether the innovation activities that led to technological progress were different or not, but in reality, there are many different innovation activities. They rely on different basic knowledge and form different new knowledge. On the one hand, the "learning by doing" and knowledge innovation ability within the department will strengthen the initial technical level, so that the evolution of technological progress will be characterized by persistence.

On the other hand, the technology spillover brought by cross-border trade and the difference in the speed of technological catch-up between different sectors may cause the reversal of technological level, thus making the change of technological progress mobility. Relevant technical capability empirical research also shows that since any new technology can only be developed on the basis of existing technology, the innovation of technical products has strong path dependence and self-accumulation characteristics. In addition to the drylearning effect, the $R \& D$ input of enterprises is also very important for technological progress, because enterprises or countries can improve their capabilities through imitation and learning when their technological level is low, but when their technological level is high, enterprises or countries can only expand their technological boundaries by increasing $R \& D$ innovation activities.

It can be seen from the above that for the economic transformation faced by China and India, the technical capacity in the economic sense should be a comprehensive capacity for technological upgrading, transformation and innovation that is suitable for the development of dynamic comparative advantages formed in the process of growth. When China and India have strong technical capacity, it means that the dynamic degree of their comparative advantage will be relatively increased, the volume of international trade will increase correspondingly, and the economy will show such phenomena as the increase of explicit comparative advantage, the increase of market concentration and the improvement of terms of trade.

\section{NATIONAL CAPACITY GROWTH, TECHNOLOGICAL PROGRESS AND KNOWLEDGE ACCUMULATION EFFECT}

Economic historian Gershenkelon has long noted that in the world economic development history marked by modern industrialization since the mid-19th century, a few countries can catch up from the backward state of economy, while many other backward countries fall into the poverty trap. In response to this phenomenon, Geshenkron tries to answer by analyzing the relationship between technological progress, capacity and development. Since the beginning of the 21 st century, with the academic rethinking of the Washington consensus, the concept of "national capacity" has been fully discussed and applied in political science and other disciplines. In particular, Francis Fukuyama, an American scholar, put forward a basic theoretical framework for analyzing the growth of ability in his book "National Construction", and pointed out to some 
extent that capability refers to the institutional capacity of a country to a certain extent.

As economists pay attention to economic growth especially the source of technological progress in recent years, they begin to pay attention to the importance of ability in technological progress. For example, in response to how to explain the different development performance of different countries in economic history, Nelson has pointed out that, in addition to natural endowments, capital and labor, which are directly related to economic growth, "Social capacity" also affects the economic development performance of a country and region in economic activity, while technological progress based on knowledge accumulation and development strategies and organizational structures related to enterprise capacity, The dynamic formation of elements such as the evolution of economic system has undoubtedly become an important source of this capability. In addition, after examining over a long period of time the historical experience of nearly 500 years of world economic development, Reinert found that when Germany and the United States were still developing countries, they wanted to develop industry against British preaching. The reason for this is that Germany and the United States recognize that when factors such as labor and capital are put in production activities in the primary product sector, which depend on natural endowment elements, On the contrary, income from new labor and capital per unit decreases; Production activities in the industrial and service sectors, which rely on factors of technological progress and innovation, can gradually reduce the cost per unit of products and services due to higher productivity. By imitating and learning the production technology and organizational structure of advanced countries, Germany and the United States soon realized the transformation from diminishing compensation to increasing reward, and overtaken the British economy. These economic historical facts reveal that economically backward countries can improve their technological capabilities by introducing and absorbing advanced countries' technologies and managerial and organizational experiences, so as to catch up with developed countries.

Accordingly, these four sources of capacity are also closely related to the evolutionary stage of technological progress in developing countries. For developing countries, technological progress is not only the expansion of the technological level at the enterprise level, but also the integration of domestic knowledge accumulation and R\&D innovation activities. At the same time, as national capacity is a kind of endogenous renewal capacity of technology with the characteristics of knowledge accumulation, it can form the internal foundation and support system for the dynamic comparative advantage of developing countries in economic transformation, so it cannot be simply equated with technological innovation capacity in general sense. In addition, it is generally believed that the technological capability at the enterprise level can be acquired through the self-learning of enterprises and individuals, while the technological innovation capability at the national level can only be acquired through a special path, that is, the economic development strategy in line with the country's comparative advantages must be implemented. Therefore, in order to achieve successful economic transformation, the developing countries represented by China and India must transform their economic development mode as soon as possible, that is, to realize the technological progress mode based on the growth of independent innovation capability as soon as possible.

\section{COMPARISON OF TECHNOLOGICAL PROGRESS BETWEEN CHINA AND INDIA UNDER OPEN CONDITIONS: AN EMPIRICAL ANALYSIS BASED ON TFP}

Based on the traditional thought of "growth accounting", there are three main measurement methods for technological progress, namely, the neo-classical measurement method initiated by economist Solow in 1957 and the stochastic frontier function method (SFA,) put forward by Aigner et al in 1977. Stochastic Frontiers Analysis), and non-parametric analysis method based on data envelopment (DEA, Data Envelopment Analysis). On the basis of the previous theoretical analysis, in order to explore the influence of capability factors on the technological progress of China and India, this paper will make an empirical analysis of the relationship between them.

For China and India, two developing countries, FDI has played an important role in acquiring advanced technologies in the past two decades. It not only serves as a shortcut to introduce production technology, cutting-edge R\&D technology and professional management, but also plays a role in promoting the vitality of market competition in the two countries. Since the research objective of this paper is to investigate the impact of national capacity on the technological progress of China and India, FDI inflow level can be regarded as an important indicator to evaluate national capacity, and the inter-provincial total factor productivity change can be used as the proxy indicator of technological progress. The following is an econometric model built on the basis of theoretical model by introducing FDI index

$$
\begin{aligned}
\text { FPgrowth }_{i t}= & \omega+\alpha \ln (\text { initialTFP })_{i t}+\beta \ln (h)_{i t}+\gamma \ln (p)_{i t} \\
& \lambda\left({\text { government })_{i t}}+\delta(F D I)_{i t}+\phi(\text { trade })_{i t}+\eta_{i t}+\varepsilon_{i t}\right.
\end{aligned}
$$

In the above formula, is the constant, is the provincial code of China and India, is the time, is the change of total factor productivity, is the distance between the two countries and the technological frontier,( to compare the objects in the United States, the use of the value of the after the logarithmic), is the various provinces and regions of human capital, is the population of each province, is the government spending, is the two countries the introduction of foreign direct investment, is the two countries' trade growth, is the two countries fixed effects of various provinces, is the random error of observation.

It should be noted that the data of this empirical study are mainly from OECD database, international statistical yearbook over the years and PWT6.3 database of university of Pennsylvania. Considering the source and reliability of data, Malmquist index method was used to measure total factor productivity of 28 provinces and cities in China and 28 states in India from 1970 to 2011.Human capital variables mainly 
use workforce average education years calculated, the population variable is used in China's 2010 census statistics, India's 2011 census statistics, the government expenditure scale variables by both China and India between 10 and 2011 the government fiscal spending as a share of GDP, variables using the United Nations conference on trade and development (UNCTAD) provided by the data from 1970 to 2011, while trade growth variables using the two countries import and export of goods and services in 1970-2011 GDP.

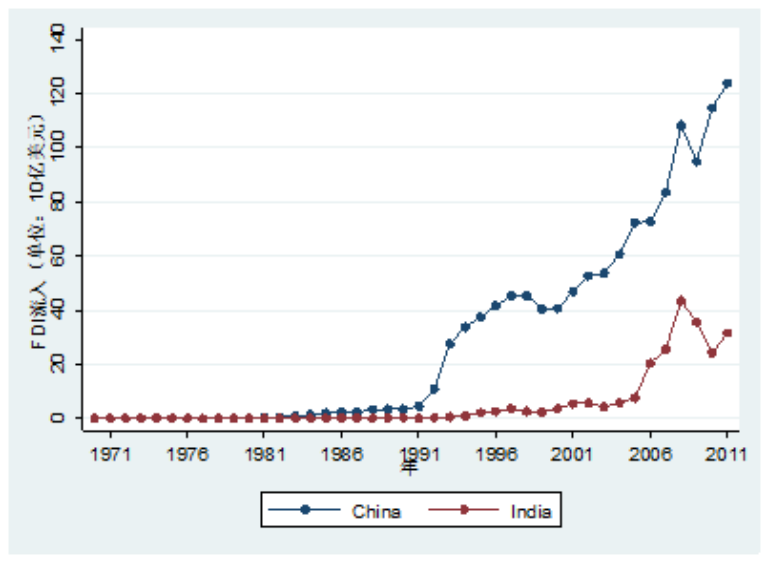

Figure 1: scale of FDI imports from China and India in 1970-2011

An interesting phenomenon can be found from figure 1 . China's economic reform started in 1979, while India's economy started to take off in 1982. Correspondingly, the inflow of the two countries also fluctuates with economic growth. This also preliminarily confirms the judgment on the relationship between China and India and economic growth in the previous theoretical analysis, that is, with the inflow, the national capacity of China and India is improved and has a positive effect on economic growth. Of course, the more interesting question in this paper is, if China and India catch up with developed countries rapidly due to the late-moder advantage of technological progress, then what causes the convergence caused by technology spillover? Is there a more fundamental mechanism for introducing the resulting change in national capacity that determines the difference in growth performance between China and India?

An interesting phenomenon can be found from figure 1 . China's economic reform started in 1979, while India's economy started to take off in 1982. Correspondingly, the inflow of the two countries also fluctuates with economic growth. This also preliminarily confirms the previous theoretical analysis of the relationship between economic growth and , that is, with the inflow, the national capacity of China and India has been enhanced and thus has a positive effect on economic growth. Of course, the more interesting question in this paper is, if China and India catch up quickly with the developed countries because of the late advantage of technological progress, what is the cause of the convergence caused by the spillover of technology? Is there a more fundamental mechanism for introducing changes in national capacity to determine the difference in growth performance between China and India?

In the empirical study, this paper mainly USES four regression estimation models. For comparison, respectively, using the first table 1 (1) and (5) column represents mixed regression method of least square (pooled OLS estimation results, the first column (2) and (6) on behalf of the robust regression method (robust regression) estimation results, the first column (3) and (7) on behalf of the fixed effects regression (fixed - effects, FE) panel as a result, the first column (4) and (8) on behalf of the system of generalized moment (dynamic panel system GMM) estimation results. At the same time, in order to illustrate the applicability of the generalized moment sGMM model of the system, Arellanobond and Hansen tests are made on it. The results show that the null hypothesis is rejected at the significance level of $1 \%$, which indicates that the sGMM model can be selected

Table 1: panel regression results of the effect of national capacity on technological progress in China and India

\begin{tabular}{|c|c|c|c|c|c|c|c|c|}
\hline & \multicolumn{4}{|c|}{$\begin{array}{c}\text { The dependent variable of I: } \\
\text { China TFPgrowth(\% per } \\
\text { annum) }\end{array}$} & \multicolumn{4}{|c|}{$\begin{array}{l}\text { The dependent variable of } \\
\text { II: India TFPgrowth(\% per } \\
\text { annum) }\end{array}$} \\
\hline & (1 & )$^{(2}$ & )$^{(3}$ & )$^{(4}$ & )$^{(5}$ & )$^{(6}$ & $\begin{array}{l}(7 \\
)^{2}\end{array}$ & )$^{(8}$ \\
\hline $\begin{array}{c}\text { Explanatory } \\
\text { variable }\end{array}$ & OLS & $\begin{array}{c}\text { Rob } \\
\text { ust }\end{array}$ & $\mathrm{FE}$ & $\begin{array}{c}\mathrm{sG} \\
\mathrm{MM}\end{array}$ & OLS & $\begin{array}{c}\text { Rob } \\
\text { ust }\end{array}$ & FE & $\begin{array}{c}\mathrm{sG} \\
\mathrm{MM}\end{array}$ \\
\hline $\begin{array}{l}\operatorname{Ln}(\text { initialTF } \\
\mathrm{P})\end{array}$ & $\begin{array}{c}- \\
1.17 \\
5^{* *} \\
* \\
(0.3 \\
17)\end{array}$ & $\begin{array}{c}- \\
1.12 \\
4 * * \\
* \\
(0.2 \\
3)\end{array}$ & $\begin{array}{c}- \\
6.03 \\
9 * * \\
* \\
(0.6 \\
51)\end{array}$ & $\begin{array}{c}- \\
1.50 \\
8^{* *} \\
* \\
(0.5 \\
4)\end{array}$ & $\begin{array}{c}- \\
1.16 \\
2 * * \\
* \\
(0.3 \\
97)\end{array}$ & $\begin{array}{c}- \\
1.13 \\
4 * * \\
* \\
(0.2 \\
91)\end{array}$ & $\begin{array}{c}- \\
5.86 \\
2 * * \\
* \\
(0.7 \\
4)\end{array}$ & $\begin{array}{c}- \\
2.77 \\
0 * * \\
* \\
(0.8 \\
09)\end{array}$ \\
\hline $\operatorname{Ln}(\mathrm{h})$ & $\begin{array}{c}0.96 \\
3 * * \\
* \\
(0.3 \\
77)\end{array}$ & $\begin{array}{c}0.79 \\
7 * * \\
* \\
(0.2 \\
67)\end{array}$ & $\begin{array}{c}0.91 \\
2 \\
(0.8 \\
76)\end{array}$ & $\begin{array}{c}0.97 \\
2 \\
(0.6 \\
75)\end{array}$ & $\begin{array}{c}0.87 \\
3 * \\
(0.4 \\
59)\end{array}$ & $\begin{array}{l}0.77 \\
5 * * \\
(0.3 \\
43)\end{array}$ & $\begin{array}{c}1.03 \\
0 \\
(0.9 \\
60)\end{array}$ & $\begin{array}{c}0.18 \\
2 \\
(0.8 \\
28)\end{array}$ \\
\hline $\operatorname{Ln}(p)$ & $\begin{array}{c}0.17 \\
8 \\
(0.1 \\
39)\end{array}$ & $\begin{array}{l}0.16 \\
(0.1 \\
04)\end{array}$ & $\begin{array}{c}- \\
2.05 \\
5^{*} \\
(1.0 \\
92)\end{array}$ & $\begin{array}{c}- \\
0.01 \\
1 \\
(0.4 \\
86)\end{array}$ & $\begin{array}{c}0.21 \\
8 \\
(0.1 \\
80)\end{array}$ & $\begin{array}{l}0.27 \\
8 * * \\
(0.1 \\
41)\end{array}$ & $\begin{array}{c}- \\
2.27 \\
3 * \\
(1.1 \\
65)\end{array}$ & $\begin{array}{c}0.24 \\
1 \\
(0.5 \\
08)\end{array}$ \\
\hline $\begin{array}{l}\operatorname{Ln}(\text { governm } \\
\text { ent) } \\
(\% \text { of GDP) }\end{array}$ & $\begin{array}{c}- \\
0.02 \\
4 \\
(0.0 \\
19)\end{array}$ & $\begin{array}{c}- \\
0.02 \\
7 \\
(0.0 \\
17)\end{array}$ & $\begin{array}{c}- \\
0.00 \\
4 \\
(0.0 \\
38)\end{array}$ & $\begin{array}{c}- \\
0.13 \\
1 * * \\
(0.0 \\
58)\end{array}$ & $\begin{array}{c}- \\
0.02 \\
4 \\
(0.0 \\
19)\end{array}$ & $\begin{array}{c}- \\
0.02 \\
9 \\
(0.0 \\
21)\end{array}$ & $\begin{array}{c}- \\
0.01 \\
4 \\
(0.0 \\
39)\end{array}$ & $\begin{array}{c}- \\
0.16 \\
4 * * \\
(0.0 \\
66)\end{array}$ \\
\hline $\begin{array}{l}\text { Ln(trade) } \\
\text { (percent) }\end{array}$ & $\begin{array}{c}0.01 \\
1 \\
(0.0 \\
57)\end{array}$ & $\begin{array}{c}0.02 \\
7 \\
(0.0 \\
32)\end{array}$ & $\begin{array}{c}0.04 \\
2 \\
(0.0 \\
43)\end{array}$ & $\begin{array}{c}- \\
0.03 \\
5 \\
(0.0 \\
52)\end{array}$ & $\begin{array}{c}0.01 \\
2 \\
(0.0 \\
63)\end{array}$ & $\begin{array}{c}0.04 \\
8 \\
(0.0 \\
4)\end{array}$ & $\begin{array}{c}0.03 \\
6 \\
(0.0 \\
50)\end{array}$ & $\begin{array}{c}- \\
0.00 \\
0 \\
(0.0 \\
49)\end{array}$ \\
\hline $\begin{array}{c}\mathrm{Ln}(\mathrm{FDI}) \\
\text { (\% of GDP) }\end{array}$ & $\begin{array}{c}0.34 \\
7 * * \\
* \\
(0.0 \\
98)\end{array}$ & $\begin{array}{c}0.35 \\
8 * * \\
* \\
(0.0 \\
82)\end{array}$ & $\begin{array}{c}0.39 \\
8 * * \\
* \\
(0.1 \\
12)\end{array}$ & $\begin{array}{c}0.35 \\
1 * * \\
* \\
(0.1 \\
18)\end{array}$ & $\begin{array}{c}0.30 \\
8 * * \\
* \\
(0.0 \\
74)\end{array}$ & $\begin{array}{c}0.27 \\
7 * * \\
* \\
(0.0 \\
62)\end{array}$ & $\begin{array}{c}0.33 \\
8 * * \\
* \\
(0.0 \\
77)\end{array}$ & $\begin{array}{c}0.25 \\
1 * \\
(0.1 \\
31)\end{array}$ \\
\hline $\begin{array}{l}\text { Arellano- } \\
\text { Bond test }\end{array}$ & & & & $\begin{array}{l}0.83 \\
{[0.2} \\
641]\end{array}$ & & & & $\begin{array}{l}0.48 \\
{[0.0} \\
001]\end{array}$ \\
\hline Hansen test & & & & $\begin{array}{l}0.12 \\
{[0.2} \\
701]\end{array}$ & & & & $\begin{array}{l}0.57 \\
{[0.1} \\
052]\end{array}$ \\
\hline $\begin{array}{c}\text { Observed val } \\
\text { ue }\end{array}$ & $\begin{array}{c}114 \\
8\end{array}$ & $\begin{array}{c}114 \\
8\end{array}$ & $\begin{array}{c}114 \\
8\end{array}$ & $\begin{array}{c}114 \\
8\end{array}$ & $\begin{array}{c}114 \\
8\end{array}$ & $\begin{array}{c}114 \\
8\end{array}$ & $\begin{array}{c}114 \\
8\end{array}$ & $\begin{array}{c}114 \\
8\end{array}$ \\
\hline
\end{tabular}


Note :() is the heteroscedasticity robust standard error of the regression coefficient, and [] is the $p$ value of the corresponding test statistic; ***, ** and * represent the significance levels of $1 \%, 5 \%$ and $10 \%$ respectively.

Next, the regression results of columns (1) - (4) in table 1 are specifically analyzed, and the conclusions are also applicable to the regression results of columns (5) - (8). First, the signs of variable correlation coefficients obtained by the four regression models are all negative, and all of them have passed the $1 \%$ significance level test, indicating that the initial level of is negatively correlated with the growth rate of . At the same time, the results can also be found from four kinds of estimation method of difference, OLS estimates of the coefficient is 1.18 , and the Robust estimation results -1.12 , while the estimated coefficient $t$ of FE high of 6.04, sGMM generalized moment estimation results for 1.51, somewhere between the two, it shows that the result of generalized moment method is closer to a steady convergence speed estimation; Second, although the coefficient of human capital was positive, it did not show statistical significance in the regression of FE and SGMM, but passed the significant test at the level of $1-5 \%$ in OLS and Robust regression, indicating that human capital investment had a certain promoting effect on technological progress. Thirdly, the correlation coefficient symbols of variables such as population, government expenditure scale and trade growth were consistent with the expected results in OLS and Robust regression, indicating that population and trade growth had a positive effect on change, and the larger the government expenditure scale was, the greater the hindrance to technological progress was. Fourth, the correlation coefficient of the key variables passed the 1$10 \%$ significance test of the four models, and the signs were positive, indicating that each $1 \%$ increase of would lead to an increase of $35-39 \%$ of.

\section{CONCLUSION}

Through the empirical analysis based on capacity growth perspective, can be found: first of all, evidence of China's technological progress much faster than India, compared with several other factors such as population, trade, and the size of government, the effect of technological progress level of convergence in the biggest, this also verify the judgment of the front theoretical analysis, the index reflects the latedevelopment country accumulated knowledge and technical ability level, the growth of one country by introducing the ability to get stronger, and the higher levels of the country's technological progress. Secondly, after controlling for other factors affecting technology level, the results of panel regression based on changes consolidate the understanding of this paper on the role of technology diffusion in catch-up countries. There is no doubt that as a contain elements such as technology, capital, management, and system of "composite products," is not only between the two countries is a major source of technological progress, and flows also can cause the spread of the advanced technology and management methods, so as to improve the factor productivity, and indirectly promote the effect of economic growth in developing countries. Finally, the growth experience of China and India tells us that technological progress is a cumulative process of long-term learning and imitation of advanced technologies, and correspondingly, the growth of national capacity is the key to success. Without the ability to absorb and innovate accumulated knowledge, technology spillovers simply cannot be sustained.

China and India still rely heavily on government-led capital investment to promote economic growth. This has resulted in the high proportion of manufacturing industry in the industrial structure of the two countries, while the low proportion of technology-intensive industries and services, unable to meet the needs of the global market. Because the economy has been in extensive development relying on external technology and capital for a long time, which hinders the capacity growth of China and India, the economic growth of the two countries will slow down when the international economic environment changes. In the future, the economic development of China and India will still face many uncertainties. Whether they can successfully overcome the middle-income trap and achieve economic transformation is an unknown question. For China and India, facing the critical period of economic transformation, they will face greater setbacks and challenges in the future if they fail to achieve real development in building national capacity based on independent innovation. Therefore, this paper holds that it is necessary to solve the problems of technological progress and capacity growth in China and India from three aspects:

Firstly, in order to achieve rapid industrialization and sustainable economic growth, China and India must pay attention to the impact of international trade on technology diffusion and spillover. Under the condition of open economy, developing countries can often obtain opportunities for learning and technology spillover from the import and export of products, which in turn strengthens the dependence of technological progress on trade. The path of technological progress between China and India shows that economic openness needs to be further improved. Only by deepening the role of trade in technological spillover can the two countries move closer to the technological frontier as soon as possible. As far as external conditions are concerned, trade openness is crucial to China and India's capacity growth. Reducing tariff barriers and encouraging imports are the key to productivity improvement, because only in this way can domestic economy truly integrate into international competition and enable domestic enterprises to learn advanced technology from abroad, so that their products will have international competitiveness.

Secondly, the experience of developing countries such as China and India has proved that free trade has not locked them in a backward position, but has brought them dynamic comparative advantages characterized by export-oriented development. In order to maintain comparative advantage, it is necessary for China and India to continue to guide their industrial development through policy intervention, especially strategic economic policies, in order to solve the structural imbalance in the economy. According to the characteristics of the current technological progress in India and China, we can see that the sustainability of India is facing serious challenges in the future, because it has neither achieved the upstream 
position in the international industrial chain nor realized the dynamic optimal allocation of resources in the rapid economic growth. Therefore, the governments of China and India need to combine national capacity with technological progress, and implement the economic development mode with independent innovation as the core as soon as possible, so as to promote the transformation of technological progress, organizational behavior and institutional system, so as to realize the transformation of economic development mode of China and India through the growth of national capacity.

Thirdly, improving the contribution rate of technological progress, especially technological innovation, to growth is undoubtedly the key to the successful economic transformation of China and India in the future. To this end, China and India need to increase their investment in independent $\mathrm{R} \& \mathrm{D}$, change the past technology progress mode, which mainly focuses on equipment introduction and renewal, and rely on technological innovation to drive technological progress.

\section{REFERENCES}

[1] Amiti, M. , and C. Freund. “An Anatomy of China's Export Growth”, in Robert Feenstra and Shang-Jin Wei (eds.), China's Growing Role in World Trade[M].University of Chicago Press, 2016.

[2] Caniels, C.J., Verspagen, B., "Barriers to knowledge spillovers and regional convergence in an evolutionary model ", Journal of Evolutionary Economics, Vol.11, 2001, pp.307-329.

[3] Coe, D., and E. Hhelpman. "International R\&D Spillovers", European Economic Review, Vol. 39, 1995, pp.859-887.

[4] Criscuolo , P., Narula , M , "A novel approach to national technological accumulation and absorptive capacity: aggregating Cohen and Levinthal" , The European Journal of Development Research, Vol.20, 2008, pp.56-73.

[5] Harrison, A., and A. Rodriguez-clare, " Trade, Foreign Investment and Industrial Policy for Developing Countries" , NBER Working Paper, 2015,

[6] R. Nelson, "How new is new growth theory ?" , Challenge, Vol.40, 1997, pp.29-58.

[7] Parente, S., and E. Prescott, "Barriers to Riches" , MIT Press, Cambridge, MA, 2001.

[8] E. Reinert, "How rich countries got rich $\cdots$ and why poor countries stay poor" , New York : Carroll \&Graf Publishers, 2017. 